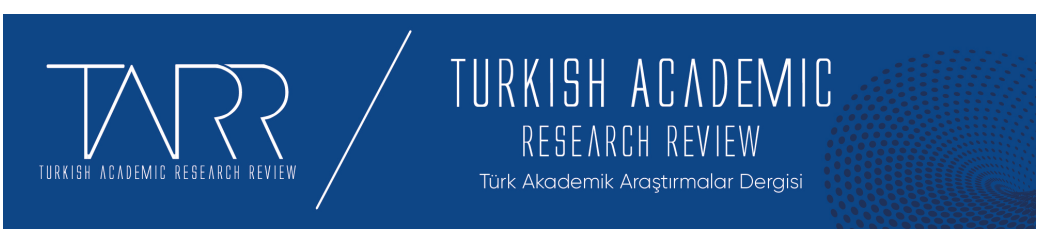

e-ISSN: 2602-2923 Yıl/Year: 2021 Cilt/Volume: 6 Sayı/Issue: 4

\title{
Gazali'de Yanılan Bir Varlık Olarak İnsan
}

Human As A Mistaken Being İn Al-Ghazali

\section{İlim Esra EREK - Önder BíLGIN}

Doktora Öğrencisi, Akdeniz Üniversitesi, Sosyal Bilimler Enstitüsü, Felsefe Anabilim Dalı/ Ph.D. Student, Akdeniz University, Institute of Social Sciences, Department of Philosophy, esra.erek58@gmail.com Orcid.org/ 0000-0001-86928333.

Doç. Dr., Akdeniz Üniversitesi, Edebiyat Fakültesi Felsefe Bölümü, Felsefe Tarihi ABD / Assoc. Prof. Dr., Akdeniz University, Faculty of Letters, Department of Philosophy, History of Philosophy, Antalya, Turkey, obilgin@akdeniz.edu.tr, Orcid.org/0000 000265330209.

\begin{tabular}{r|l} 
Makale Bilgisi & Article Information \\
Makale Türü - Article Type & Araştırma Makalesi / Research Article \\
Geliş Tarihi - Date Received & 14 Kasım / November 2021 \\
Kabul Tarihi - Date Accepted & 25 Aralık / December 2021 \\
Yayın Tarihi - Date Published & 31 Aralık / December 2021 \\
Yayın Sezonu & Aralık Özel Sayı \\
Pub Date Season & December Special Issue
\end{tabular}

Atıf/Cite as: Erek, İ.E.-Bilgin, Ö., (2021), Gazali'de Yanılan Bir Varlık Olarak İnsan/ Human As A Mistaken Being in Al-Ghazali. Turkish Academic Research Review, 6 (4), 66-84. Retrieved from https://dergipark.org.tr/tr/pub/tarr/issue/67631/1023413

Intihal / Plagiarism: Bu makale, en az iki hakem tarafından incelenmiş ve intihal içermediği teyit edilmiştir. / This article has been reviewed by at least two referees and confirmed to include no plagiarism. https://dergipark.org.tr/tr/pub/tarr

Copyright (C) Published by Mehmet ŞAHIN Since 2016- Akdeniz University, Faculty of Theology, Antalya, 07058 Turkey. All rights reserved.

Turkish Academic Research Review - Türk Akademik Araştırmalar Dergisi 


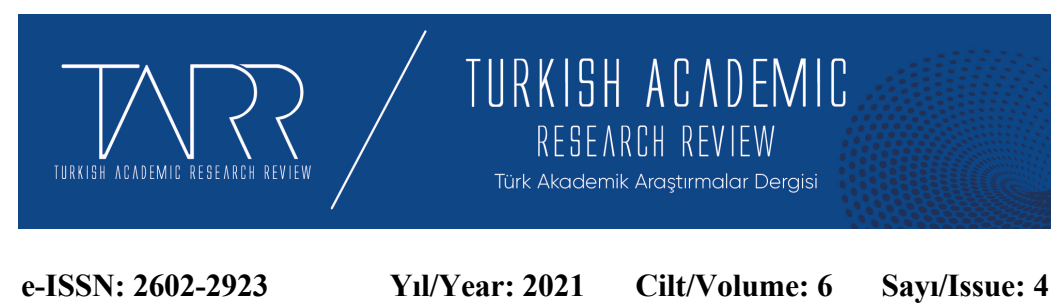

\title{
Gazali’de Yanılan Bir Varlık Olarak İnsan ${ }^{1}$
}

\author{
İlim Esra EREK - Önder BİLGİN
}

\section{$\ddot{O} \mathbf{z}$}

Makalede Gazali'nin insan anlayışı, epistemolojisi doğrultusunda yeni bir okumaya tabi tutulmuştur. Gazali'de insanın özsel niteliği akıldır. Ancak o, aklı doğru bilgi için yeterli görmez. Gazali'nin akla yönelik bu tutumu onun ne kadar tutarlı olduğunu sorguya açar. Onun insanı ve aklı nasıl anlamlandırdığı açık hale getirildiği takdirde akıl anlayışının tutarlı olup olmadığını konuşmak daha mümkün hale gelecektir.

Gazali'nin epistemolojisi incelendiğinde onun insanın bilme edimini tecrübe ile başlattı̆̆ görülür. Ayrıca aklı aynaya benzetir. Gazali'nin aklı aynaya benzetmiş olması bilginin hem nasıl mümkün olduğunu hem de insanın neden yanıldığını açıklar. Ayna yansıtma gücüyle dışarıyı görmeye olanak sağlar. Ancak kişinin bilgisi aynaya bağımlıdır. Yani aynanın yansıtma gücü nispetinde görebilir. Ayna akıl olduğuna göre insanın anlama ve algılama yetisi tecrübenin etkisi içerisinde işler. Dolayısıyla insan bilgiyi doğrudan ve saf bir şekilde edinemez. İnsanın bilme süreci böyle bir yapı içerisinde işlediğine göre insan daima yanılgı ihtimaliyle karşı karşıyadır. Ancak Gazali’nin eserlerinde aklı tek bir biçimde kullanmadığı da görülür. İnsanın düşünme sürecini ifade eden akıl yani 'zihin' insani ve hayvani nefsi içinde barındırır. İnsanı doğru bilgiye götüren ve onu gerçek anlamda diğer varlıklardan ayıran akıl ise tek başına 'insani nefs' tir. Yani Gazali akıl derken her zaman bütüne değil, bazen o bütünün içindeki parçalara işaret eder. İnsani nefs 'saf akıl' olarak da nitelenebilir. Bu haliyle o insanın cevheridir. Ancak cevher yaratılmışa ait bir nitelik olup anlam ve önemi varlığın izahını yapmaya yarıyor oluşudur. Cevherin varlığın esası olmaması Gazali'nin insanı değerlendiris șekline etki eder. Gazali insanı ona ilişen ilineklerden ve cisminden bağımsız değerlendirmez. Hayvandan akıl ile ayrilyyor olsa da hayvanla ortak olan ruh ve cisim gibi özellikleri de onu kuşatan niteliklerdendir. Bu nitelikler insan yaşadığı müddetçe ondan ayrılamadığına göre insan akıl sahibi bir varlık olduğu kadar yanılan da bir varlıktır.

Anahtar Kelimeler: Gazali, İnsan, Akı1, Yanılma, Cevher, Ayna, Tecrübe

\section{Abstract}

\section{Human As A Mistaken Being in Al-Ghazali}

Al- Ghazali's concept of the human is subjected to a re-reading in line with his epistemology in this article. The essential attribute of the human is the mind in AlGhazali. But he doesn't see the mind sufficient for the right information. This attitude of Al-Ghazali towards the mind opens the query of how consistent he is. If it could be clarified how he makes sense of human and mind, it will be more possible to talk about whether the understanding of reason is consistent or not.

When Al-Ghazali's epistemology is inquired it is seen that the act of knowing starts

${ }^{1} \mathrm{Bu}$ makale, İlim Esra Erek tarafından, Doç. Dr. Önder Bilgin’in danışmanlığında, Akdeniz Üniversitesi Sosyal Bilimler Enstitüsü Felsefe Anabilim Dalında Ocak 2021 tarihinde kabul edilen "Gazali' de İnsan Ve Hakikat" başlıklı Yüksek Lisans Tezinden yapılan bazı değişiklik ve değerlendirmelerle üretilmiștir. Tez, Ekim 2021 tarihinde Aktif Düşünce Yayıncılık tarafından aynı isimle kitap olarak yayımlanmıştır.

Turkish Academic Research Review - Türk Akademik Araştırmalar Dergisi 
with the experience. He also compares the mind to a mirror. Al-Ghazali's comparing the mind to a mirror explains both how the information is possible and why the human mistake. The mirror allows us to see the outside with its power of reflectivity. But the information of the human is dependant the mirror. That is, the human could see in proportion to the reflecting power of the mirror. If the mind is mirror, understanding and perception of human works under the influence of experience. Thus, the human can't have the information directly and purely. The human always faces the probability of a mistake, because the human act of knowing works in this structure. However, it's seen also Al-Ghazali does not use the mind in a single means in his works. The mind, that is the 'consciousness', expressing the thinking process of man contains the human and animal soul. The mind leading people to the right information and distinguishing he/she from the other beings truly is the 'human soul' alone. In that case, Al-Ghazali sometimes indicates the parts of the whole, not always the whole with the concept of mind. The human soul could be expressed also as 'pure mind' whereby being the substance of the human. But the substance is an attribute of the created and it's mean and important originates to explain the existence. As the substance isn't the essence of existence, it affects Al-Ghazali's way of evaluating humans. Al-Ghazali does not evaluate the human independently of his/her accidents and the body. Even If the human separates from the animal with the mind, it is the feature such as spirit and body, which are common with animals. They are among the qualities that surround the human. If these qualities cannot be separated from his/ her as long as a person lives, the human is a mistaken being as much as is a rational being.

Keywords: Al-Ghazali, Human, Mind, Mistake, Substance, Mirror, Experience

\section{Structured Abstract}

Al- Ghazali's concept of the human is subjected to a re-reading in line with his epistemology in this article. The aim is to clarify that on what basis does the human and his/her act of knowing function in Al-Ghazali. It is known that the human essential qualification is mind in Al-Ghazali. Despite the fact that, he doesn't have enough of the mind for the right information and makes important criticisms, this attitude of AlGhazali opens to the query of how consistent he is. If it $t$ could be clarified how he makes sense of human and mind, it will be more possible to talk about whether the understanding of reason is consistent or not.

According to Al-Ghazali, the human is what cannot be expressed with a single definition. But the real definition has to be a single definition is for could to be created conceiving the essence of that thing. The human couldn't be expressed with a single definition and is required to use some definition and limitation to understand it. $\mathrm{He}$ does it since he has to understand and express it just in this way. For this reason, AlGhazali doesn't have identical explanations and definitions in his books. However, there is a human picture that can be noticed by everyone and this indispensable of the picture is 'the mind'. So, what was inquired is how he had been handling the mind and its process of knowing. He divides the nafs into three parts: vegetative, animal, and human as there is Aristotle's sense of soul. The human knowledge process starts with the perception and comprehension faculties of the animal nafs. Besides, according to Al-Ghazali, the human doesn't have even the most basic information that can be seen as a priori information in his/her when starting to the created. It reaches to his/her with "a careful look and the slightest inference." Therefore, the starting of information is under the influence of experience even if it's small in Al-Ghazali. Especially his comparing the mind a mirror draws attention. It explains both how the information is possible and why the human mistake. The mirror allows us to see the

Turkish Academic Research Review - Türk Akademik Araştırmalar Dergisi 
outside with its power of reflectivity. But the information of the human is dependent on the mirror. That is, the human could see in proportion to the reflecting power of the mirror. If the mind is a mirror, understanding, and perception of human works under the influence of experience. Thus, the human can't have the information directly and purely. The human always faces the probability of a mistake, because the human act of knowing works in this structure. However, it's seen also Al-Ghazali does not use the mind in a single means in his works. The mind, that is the 'consciousness', expressing the thinking process of man contains the human and animal soul. The mind leading people to the right information and distinguishing he/she from really other beings is the 'human soul' alone. In that case, Al-Ghazali sometimes indicates the parts of the whole, not always the whole with the concept of mind. The human soul could be expressed also as 'pure mind' whereby being the substance of the human. It's substance of human at that rate. If the essence of the human is 'pure mind' detached from the senses, the human could achieve the exact information when the human can get rid of the body. But, it is an inference attained conclusion by isolating the mind from the human condition. In other words, the human mind isn't mistaken can be possible just when the mind is considered separately from the human. The place of this claim could be based on his concept of substance in Al-Ghazali's think. According to Al Ghazali, the substance is an attribute of the created, and it's mean and importance originates to explain the existence. As the substance isn't the essence of existence, it affects Al-Ghazali's way of evaluating humans. Al-Ghazali does not evaluate the human independently of his/her accidents and the body. Even if the human separates from the animal with the mind, it is the feature such as spirit and body, which are common with animals. Also, Ghazali's critique in Tehafüt is based on this point. At the source of the problem is the inability of reasoning based on pure reason to determine the truth. Human is not only surrounded by the limitations of the world also have to act other words, change as long as he/she lives in the world. That is, the human cannot remain in a stable structure.

In conclusion, it's seen that he doesn't make an effort to draw definite lines or idealize them concerning his approaching the human and therefore the mind. With regard as the mind cannot be completely separated from the human, there is a linear relationship between being a rational being and being a mistaken being. And so the human is a mistaken being as much as is a rational being also.

\section{Giriş}

Makalede Gazali'nin insan anlayışı, epistemolojisi doğrultusunda yeni bir okumaya tabi tutulmaktadır. Gazali'de insanın ve onun bilme ediminin nasıl bir temel içerisinde işlediğini belirgin hale getirmek hedeflenmektedir. Bilindiği üzere Gazali aklı doğru bilginin esas dayanağı olarak görmemiş ve eserlerinde aklın yetersizliğine dair önemli kritiklerde bulunmuştur. Buna karşın Gazali, insanı akıl sahibi bir varlık oluşu üzerinden tanımlar. Peki, ama böyle bir yaklaşım çelişki oluşturmaz mı? Gazali'nin akla dolayısıyla da insana yüklediği anlam belirgin hale getirildiği takdirde onun tutarsızlık olarak nitelendirilen akıl anlayışının gerçekten tutarlı olup olmadığı üzerinde tartışmak daha mümkün hale gelecektir. 
Bir bakıma araştırma, Gazali’nin insan anlayışının nasıl bir teori üzerine kurulmuş olduğunu irdelemektedir. Ancak çalışma sınırlılılıkları nedeniyle Gazali epistemolojisi denilince akla ilk gelen 'sezgi' anlayışı çalışmanın odağında bulunmamaktadır. Çünkü burada 'bilgi' nin değil 'bilen' in neliği ve konumu soruşturulmaktadır.

Gazali’nin anlatımlarının hitap ettiği kitleye ya da eserin yazılış amacına göre değiştiği bilinmektedir. Bu durum Gazali düşüncesini belirli bir çerçeve içerisinde okumayı zorlaştırmaktadır. Çalışmada onun hemen her eseri ele alınmış ve eserlerindeki anlam ve niyete özellikle odaklanılmaya çalışılmıştır. Gazali'nin felsefeye veya havasa ilişkin eserleri daha dikkatli bir biçimde ele alınmıştır. Gazali'nin avam havas ayrımı yüzünden tartışmalarının muğlak kaldığına dikkat çekmek gerekir. Gazali'nin felsefi bir teori kurma amacı taşımamış oluşu onun düşünce sisteminin teorik bir yapısının olmadığg anlamına gelmemektedir. Bir taraftan Gazali'nin insan anlayışını nasıl bir teori üzerine kurduğu incelenirken diğer taraftan da muhataba uygun bilgi ve hüküm verme arayışı arasındaki dengede aklın rolüne odaklanılmıştır.

Diğer taraftan bu makalede Gazali’nin insanın mahiyetine ilişkin görüşleri ile yanılma arasında kurduğu ilişki problematik bir biçimde ele alınmıştır. Griffel'ın da belirttiği gibi Gazali eserlerinde insanların yargıda bulunurken nasıl yanılgılara düşebilecekleri konusunda sürekli uyarılarda bulunmaktadır (Griffel, 2009, s. 451). Yıldız da Gazali’nin akıl eleştirisinin tam bir bilgi kuramsal niteliğe sahip olduğuna dikkat çeker (Yıldız, 2011, s. 73). Gazali’nin eserlerinde aklın yanılgıları üzerinde ciddi bir şekilde durduğu görülür. Aklın hem neden ve nasıl yanılıyor olduğunu inceler hem de bu yanılgıların üstesinden nasıl gelinebilir olduğunun çarelerini arar. Biz bu araştırma içerisinde aklın 'neden' yanıldığı sorusunun üzerinde yoğunlaşacağı.

Araştırma üç ana başlıktan oluşmaktadır. Birinci başlıkta Gazali’nin insanı nasıl anlamlandırmış olduğuna bakılmış onun insanı 'akıl sahibi' bir varlık olarak tanımladığı ortaya çıkmıştır. İkinci başlık ise insandaki aklın ne anlama geldiğini soruşturmaktadır. Burada hem Gazali'nin 'akıl' derken neyi kastettiğine hem de aklın bilgiyi nasıl edindiğine bakılmıştır. Ortaya iki önemli sonuç çıkmıştır. Birincisi insanın bilgi edinme süreci tecrübeden başlar. Dolayısıyla insan sınırlı yaşantılarıyla kurulan anlam dünyası içerisinde düşünür ve her an yanılgı ihtimaliyle karşı karşıyadır. İkincisi, Gazali aklı farklı biçimlerde kullanır. İçlerinde insanı yanılmaktan kurtaran 'saf akıl' olarak da nitelendirebileceğimiz insani nefstir. Diğer varlıklardan onunla ayrıldığı için bu akıl aynı zamanda insanın cevheridir. İnsanın yanılma ile olan

Turkish Academic Research Review - Türk Akademik Araştırmalar Dergisi 
ilişkisini netleştirebilmek için üçüncü başlık altında aklın cevher oluşunun ne anlama geldiği incelenmiş̧tir. Ortaya şu sonuç çıkmıştır ki, Gazali cevheri yaratılana ait bir nitelik olarak görmekte bu doğrultuda aklın cisimden bağımsız olduğunu kabul etse de cisimden bağımsız değerlendirmemektedir. Çünkü insan cisminden gerçek anlamda ve ancak öldükten sonra kopabilir. Öyleyse insan akıl sahibi bir varlık olduğu kadar yanılan da bir varlıktır.

\section{İnsan Nedir?}

İnsan nedir? Sorusunun en bilindik cevabı, 'düşünen hayvandır' cümlesiyle Aristo'dan gelir. Bu tanımı İslam filozofları da kullanır. Tanımın bileşeni olan “düşünen” kavramının Gazali düşüncesindeki yerini incelemek Gazali’nin insan anlayışının ne olduğunu, felsefi ve mantıksal bir düzlemde görmeye olanak sağlayabilir. Bu tartışmanın detayları aşağıda yapılmıştır. Ancak öncelikle Gazali için 'insan nedir?' sorusunun tek bir tanımla ifade edilemez ${ }^{2}$ olduğunu hatırlatmak gerekir. Bununla birlikte Gazali bir şeyin ne olduğunu onun zati özelliklerini bilerek yani gerçek tanımıyla öğrenebileceğimizi söyler. "Hangi lafız olursa olsun, gerçek tanımın amacı, istifade edecek talebenin aklında bir şeyin mahiyetinin özünün tasavvurudur.” (Gazali, 2002, s.160). Akılda o şeyin 'mahiyenin özünün tasavvurunu' oluşturabilmek adına gerçek tanım tek bir tanım olmak durumundadır. Çünkü onun zati özellikleri sınırlı olmalıdır (Gazali, 2002, s. 157-161). Öyleyse insan, her ne kadar tek bir tanımla ifade edilemese de onu anlayabilmek için bir takım tanım ve sınırlandırmalar içerisine oturtmak gerekmektedir. Gazali bunu ancak bu yolla anlamak ve anlatmak zorunda kaldığı için yapmaktadır. Yani bir taraftan o anlamın hiçbir zaman onun gerçek anlamı olmadığını kabul eder. Bu nedenle Gazali eserlerinde birebir aynı açıklama ve tanımlamaları yapmaz. Ancak genel hatları herkes tarafindan fark edilebilir olan bir insan resmi vardır. Bu resmin olmazsa olmazı da 'düşünme' yani 'akıl' dır.

Gazali (2017a, s. 44), el-Me'arifu'l- Akliye kitabında Allah'ın insanı diğer varlıklardan ayırmış olduğunu söyler. Allah insanın hem diğer varlıklardan ayrılması hem de büyük âlemin bir örneği olup ona kü̧̈ük âlem denilmesi için var edilmiş en ince düşünülürleri ve duyulurları toplamıştır. İnsan bu yolla yaratılmış varlıklar arasından ayırt edilir. Ama sadece ayırt edilmez aynı zamanda insan, onun ile yani düşünmenin değeriyle hakikati beyan edebilmesi bakımından özelleşmektedir (Gazali, 2017a, s. 44). Öyleyse insanın bilme ediminin nihai gayesinde hakikate ulaşmak vardır. Gazali’nin hakikatten ne anladığı kısaca açıklanabilir. Gazali en yüce

\footnotetext{
${ }^{2}$ Aslında Gazali'de hakiki tarifin zorluğu bütün varlıklar için geçerlidir: "Zira hakiki tarifin şartlarının mevcudiyeti güçtür. Bu bütün mevcudatta böyledir.” (Gazali, 1971a, s. 28)
} 
ilmin yokluğu düşünülemeyen daimi ve ezeli ilim olduğunu söyler ve devamında ekler: "Bu niteliği Allah'ın ilminden başka hangi ilim taşıyabilir?" (Gazali, 2019b, s. 123). Bir başka eserinde ise, "Hangi ilim olursa olsun, kim ki ilmi ile Allah-u Teâlâ'yı kastederse ilmin kârını bulur ve o ilim sahibini yükseltir." (Gazali, 1974 I, s.135). Diyerek hakikate işaret etmektedir. Bu haliyle hakikat Allah ve onun değişmez ilmidir. Bunun yanında bir de şeylerin kendi içlerindeki hakikatinden söz edilebilir. Gazali (1971a, s. 17) her şeyin nefsinin onun hakikati olduğunu söyler. Dolayısıyla insanın nefsi de onun hakikatidir. Burada belirttiği nefs kalp, ruh ve akıl kavramları ile de nitelendirilebilmektedir. Hatta o çoğu eserinde aklı nefs anlamında kullanmaktadır. Öyleyse insanın bir bütün olarak neliği de 'akıl' kavramı ile ifade edilebilmektedir. Bu durumda Gazali'nin insan anlayışının ne olduğunu belirlemek bir bakıma onun 'akıl' dan ne anladığına bağlıdır.

\section{Akıl ve Bilme Süreci}

Gazali her akıl dediğiyle aynı şeyi kastetmediği için akıl anlayışını çözümlemek zorlaşmaktadır. Zorluğun üstesinden gelebilmek adına aklın ne olduğuna dair detaylı açıklamalarda bulunduğu el-Mearif, el-Mearic ve İhya olmak üzere üç ayrı eserindeki akıl tarifleri tek tek ele alınacak, diğer eserlerindeki anlatımlarıyla da yeri geldiğinde desteklenecektir. Böylece aklı kaç biçimde, hangi anlamda ve nasıl kullanmış olduğu bulunabilir.

İnceleyeceğimiz ilk eser el-Me'arifu'l- Akliye kitabıdır. El-Mearif' in hedef kitlesinin 'havas' olduğuna dikkat çekmek gerekir. Adından da anlaşılacağı üzere kitap haddi zatında insanın düşünme yetisini incelemektedir. Böyle bir esere aklın sınırlı oluşunun hamdıyla başlanılmış olması dikkat çeken bir diğer noktadır (Gazali, 2017a: 43).

Gazali el-Mearif'te düşünmenin ne olduğuna dair şöyle bir tanım verir: "Öyleyse düşünme, bir ibarenin biçimi, bir işaretin kendisi, harflerin şekli ve seslerin hecelenişi değildir. Tam tersine, düşünme, insan nefsinin, bilgisine yerleşmiş, aklına girmiş, şekilsiz ve cisimsiz soyut biçimi ifade (ibare) edebilmesidir." (Gazali, 2017a: 52). İleriki sayfalarda paralel başka birkaç tanım daha sunar: “...bu nefs bilinecek şeylerin biçimlerine yöneldiği zaman ona 'akletme' denir; düşünülürlerini ifade (ibare) etmeye muktedir olduğu zaman ona 'düşünme' denir.” (Gazali, 2017a: 59).

Gazali'nin açıklamaları onun düşünmeyi soyutlama becerisi olarak nitelendirdiğini gösterir. Ancak buradaki düşünme ve akletme zihnin bir işlevi olarak ele alınmışa benziyor. Hâlbuki Gazali akıl/nefs/ ruh/ kalp kavramlarıyla sadece zihni kastetmemekte insanın neliğini ifade etmektedir. Hatta Gazali'nin akıl derken

Turkish Academic Research Review - Türk Akademik Araştırmalar Dergisi https://dergipark.org.tr/tr/pub/tarr 
çoğunlukla kastettiğinin kalp, ruh, nefs anlamlarına gelen akıl olduğu söylenebilir (Gazali, 1971a, s. 19- 23; Gazali, 2017b, s. 26, 27). Gazali eserin bir başka yerinde ise düşünmeye dair şöyle der:

"İnsan nefsi, ne vakit kalp aynasında fertleri ve özleriyle nesnelerin hakikatlerini tasavvur eder, nefis onları dile getirebilir, zihin onları düşünebilir; akıl onların içini ve dışını kuşatırsa işte o zaman nefse düşünen adı verilir." (Gazali, 2017a: 52).

$\mathrm{Bu}$ açıklama da yukarıdaki açıklamalarla paraleldir. 'Düşünme' nefse eklenen bir şey olarak konumlanmıştır. Ona göre düşünen insan 'doğru düşünen' insandır. "İnsan varoluşuna ilkin düşünme ile başlar ve amacına doğru düşünme ile ilerler." (Gazali, 2017a: 54) der. Öyleyse zihin nesnelere yönelmek suretiyle düşünme faaliyetini yerine getirebilir ancak gerçek anlamda 'düşünen insan' olabilmek için tek başına düşünme yeterli değildir. Düşünmenin ne olduğu mahiyet bakımından birtakım parçalara ayrılmıştır.

Gazali'nin yukarıdaki ifadesinde insanın düşünmesini 'kalp aynasında nesnelerin hakikatlerini tasavvur edebilme' olarak nitelendirmiş olduğuna da dikkat çekmek gerekir:

1. Allah insanı, bir ayna gibi arıtıp, parlattı der. İnsan bu sayede Yaratıcısının tanrılığını tasavvur edip onun rabliğini kabul etmiştir. Bu sayede insan gizli bilgilere vâkıf olabilir (Gazali, 2017a: 51). Yani insan kendindeki bu ayna sayesinde aradığı hakikate erebilir.

2. Ama bu durum insanın hakikate tam olarak erişemediğinin de bir göstergesidir. Çünkü aynanın dışından bakamaz. Aynı zamanda düşünmenin, insan nefsinin ibare ve ifadesinden başka bir şey olmadığını belirtir. Hem de o yaratılışına, bilgileri öğrenmeye yatkın ama işlenmemiş boş bir cevher olarak başlamıştır (Gazali, 2017a: 57, 58). "Böylece, akıllı kişi bilecek ki, düşünen insan, Allah'ın kitabını kendine örnek alan ve Allah'ın kelimelerinin içeriklerini tasavvur eden kişidir." (Gazali, 2017a: 52).

Gazali ayna benzetmesini el-Mearic'de detaylandırır. Bilinen her şeyin bir hakikati olduğunu söyler. Bu hakikatin sureti insanın kalp aynasında belirmektedir. Gazali bu örneğin birbirinden ayrı üç unsura sahip olduğunu belirtir. 1. Ayna /Kalp 2. Şeylerin şekillenmiş suretleri/ Eşyanın hakikatleri 3. Suretin aynada beliren benzerleri / Eşyanın hakikatinin kalbe nakşı ve buna hazır oluşu. 4. Suretin aynada belirebilmesi 
için ışık/ nur vardır. Gazali bu nurun iki türlü imkânı olduğunu söyler: şeriatça Cebrail, hikmet ehlince akıl (Gazali, 1971a: 110)³.

Oldukça önemli bir analoji olan ayna benzetmesinde altı çizilmesi gereken ilk mesele Gazali'nin hem aklı hem de dini, hakikati anlayabilmemizin iki yolu olarak görmesidir. Dikkat çekilmesi gereken bir diğer husus ise her ikisinin de aslında kişiye 'doğrudan verilmiş' olmayışıdır. Vahiy doğrudan verilmiş bir 'bilgi' gibi görülebilir. Ama aslında o da akıl gibi doğruyu bulabilmek daha doğrusu 'anlayabilmek' için verilmiş̧ir. Çünkü bilgi tek taraflı işlemez. Vahyin karşısında onu anlamakla mükellef olan muhatap vardır. Bu durumda vahiy/ş̧ık/, aynaya/kalbe yansır. Ama ayna, ışı̆̆ doğru yansıtma gücü nispetinde yetkindir. Yani insanların anlayış biçimlerindeki farkl1lıklar sadece dünyayı değil, vahyi anlarken de geçerlidir. Tam da bu yüzden verili ve belirli bir kitap olmasına rağmen insanlar çeşitli fikralara ayrılmıştır.

Gazali insanın dünyaya kendi (yapısının) dışından bakamıyor olduğuna başka eserlerinde de değinmektedir. Örneğin İhya' da insanın ancak nefsini veya şimdi ya da geçmişte nefsinin taşıdığı vasıfları (yani yaşanılanı ve yaşanılmışlığı) bilebileceğini söyler (Gazali, 1974 I: 254). Benzer şekilde el-Esna'da da insanın bilgisinin eşyadan sonra olduğunu belirtmektedir. Çünkü insan eşyayı eşyaya bağlı olarak bilir (Gazali, 2019b: 85). Öyleyse insanın bilgi süreci beden kalıbı içerisinde ve onun etkileştiği sınırlı dünya ile başlar.

El-Mearic'de akıl ve onun bilme sürecinin nasıl ele alındığı detaylandıran Gazali akıl, kalp ve ruh kavramlarının 'nefs' kelimesi yerine geçebiliyor olduğuna dikkat çeker ve bunların anlam içeriklerini tek tek değerlendirir. Kimi zaman farklı anlamlara gelse de eserde akıl, kalp ve ruh kavramlarını kullandığı zaman onunla insana has nefsi kastetmiş olduğunu belirtir (Gazali, 1971a: 17- 23).

Aristo, Farabi ve İbn Sina gibi filozofların nefs anlayışında olduğu gibi nefsin nebati, hayvani ve insani olmak üzere üç yönü olduğunu söyler (Gazali, 1971a, s. 2428). Ele aldığı üçlü nefs anlayışı ile insanın bilgi edinme sürecinin hangi aşamalardan geçtiğini gösterir. Tabi cismin ilk kemali hayatını idame ettirebilmesini sağlayacak beslenme, büyüme ve çoğalmanın gerçekleşmesidir. Tüm bunlar nebati nefste hareket ile gerçekleşir. Ardından idrak etme yani şuur gereklidir. Şuur yetisi hayvani nefste gerçekleşir. Üçüncü olarak akli ihtiyariyle fiilleri işlemeye güç yetiren insani nefs vardır. Nebati nefs üzerinde durmamaktadır. Hayvani kuvveler ise kendi içerisinde

${ }^{3}$ Gazali Ayna benzetmesini Cehavir ve el-Esna'da da yapmaktadır (Gazali, 2019a, s. 31; Gazali,2019b, s. 13). Ayrica hem el-Meraic'de hem de İhya'da ayna benzetmesinden hareketle insandaki bazı noksanlıkların hakikatlerin ona nakşetmesine engel olacak beş neden sıralar ( Bkz. Gazali, 1971a: 110 115; Gazali, 1974 III: 30- 32).

Turkish Academic Research Review - Türk Akademik Araştırmalar Dergisi 
ikiye ayrılır: tahrik edici kuvvet ve fiili işlemeye sevk edici olan kuvvet. Tahrik edici kuvvet, fiili işlemeye sevk edici olan ve bizzat fiili işleyen kuvve olmak üzere ikidir. İdrak edici kuvvetler ise iç ve dış algılar olarak ikiye ayrılır. Bilgi edinme süreci bu aşamada başlar. Dış algılar insanın beş duyusu, iç algılar ise kendi içerisinde sadece idrak, sadece hafiza ve hem idrak hem de ihtiyar olmak üzere üçe ayrılır. (Gazali, 1971a, s. 24- 55). Gazali'nin bilme sürecinin nasıl gerçekleşiyor olduğuna dair yaptı̆̆ bu açıklamada dikkat çekilmesi gereken ilk nokta onun 'idrak' etmeyi hayvani kuvve içerisinde değerlendirişidir. 'İdrak' ile nitelendirdiğini bilinçsiz düşünme eylemi olarak yorumlayabiliriz. Dolayısıyla aslında düşünme ve idrak derken gerçek anlamda düşünme ve idrak kastedilmemektedir. Ama bağımsız da değildir. Zihinsel bir süreç anlatıldığı için 'idrak, şuur, düşünme' gibi kavramlar kullanılmış olmalıdır. Aynı zamanda tüm bu yetiler cismani birer kuvvet olduğu için her birinin bulunduğu cismani yerler olduğuna dikkat çekmek gerekir (Gazali, 1971a, s. 52, 53). Öyleyse işleyen bir zihne sahip olmak hayvandan ayırt edilebilmeye yetmez. Çünkü yukarıda sayılan tüm bu yetilerin bazı hayvanlarda da bulunabilmesi mümkündür (Gazali, 1971a, s. 51). Ancak tahayyül yetisi insani kuvveye bir nevi köprü olur. İdrak edilip zihne yerleşen bilgileri analiz ve sentez ile işler (Gazali, 1971a, s. 53).

İnsan asıl insani nefs ile diğer varlıklardan ayrılmaktadır. İnsani nefsin diğer nefislerden farkı bilme ediminin his ve algının ötesine geçip akıl edebilme yetisine kavuşuyor olmasıdır (Gazali, 1971a, s. 24- 28). İnsani nefs iyi bakılmaya ve mükellef kılınmaya muhtaç bir varlıktır. Bu nedenle kişinin gerçek anlamda insan olabilmesi için onu geliştirmesi ve ona göre eylemesi şartır. Her varlığın kendi zatında ulaşması gereken bir kemali olup insani hareketin kemali de doğruyu bulup ona göre davranması olacaktır. Gazali insanın fikri hareket ile özelleşmiş olsa bile her fikri hareketin doğru olmayabileceği uyarısında bulunmadan geçmez (Gazali, 1971a, s. $41)$.

Görülmektedir ki Gazali insanın bilgi edinme aşamasını duyulardan başlatmakta ve zihnin bir işlevi olan 'idrak' yetisinin hayvani nefste bulunduğunu söylemektedir. El-Mearif’te de bilginin nereden başladığına dair önemli açıklamalarda bulunur: "Bilesin ki, bu cevher, yaratılışın başlangıcında ve küçük bir et parçasına ilk yönelişinde işlenmemiş boş bir cevherdir. Fakat o, biçimleri alıcı ve bilgileri ögrenmeye yatkındır." (Gazali, 2017a, s. 58) der. Bu açıklama insanın bilmeye sıfırdan başladığı şeklinde yapılacak bir yoruma açıktır. Gazali (2017a, s. 58) sözlerinin devamında insanda ne iyi- kötü ne de bilgi-bilgisizlik nakışı olduğunu söyler. El-Munklz'da da altını çizdiği gibi her insan fitrat üzerine doğmuştur. O halde, Gazali’nin fitrattan anladığı insanın saf ve temiz bir şekilde dünyaya gelmiş olmasıdır. 
İşlenmemiş ve dünyaya geldiği andan itibaren işlenmeye başlamıştır. Yani bilmeye bir istidat ve meyil taşır. Soruşturduğumuz nokta insanın 'bilme' ye bu dünyada başlayıp başlamadığıdır.

"Nefs, yaratılışının başında, nesnelerin ilkini aldığı zaman düşünülürlerin anlamlarını alma; onun, duyulurları algılama gücü de olmaz; öncüllerin/ ilkelerin bilgileri, söz gelişi tümeller ile tikeller arasındaki ayrılık, bir şeye eşit olan şeylerin kendilerine eşit oldukları gibi bilgiler, nefste olmaz. Çünkü nefs dikkatli bir bakışla ve en küçük bir çıkarımla onlara ulaşır." (Gazali, 2017a, s. 58).

Yani nefs yaratılışına ilk başlarken onda apriori bir bilgi olarak görülebilecek en temel bilgiler dahi bulunmamaktadır. Bu ilk başlangıç "dikkatli bir bakış ve en küçük bir çıarımla" ona ulaşıyorsa bu bilgi onun herhangi bir şey ile bir temas sonrası gerçekleşmiş olmalıdır. Ufak da olsa yaşanmışlığın etkisini taşır. Keza açıklamanın devamında dölütün bebeklik dönemine geçtiğinde bazı duyularının güçlendiğini, bu duyuların çocukluk döneminde tamamlandığını belirtir. Doğal akıl ise tüm bunlar tamamlanıp kendi duyulurlarını ve parçalı şeyleri öğrenmeye başladıktan sonra oluşur. Gazali insanın gelişme süreci aşamalarının sırasıyla, yalın nefs, doğal akıl, bilkuvve akıl, bilmeleke akıl, kazanılmış akıl ve bilfiil akıl olduğunu söyler (Gazali, 2017a, s. 58, 59). Kişi doğal akıldan bir üst aşamaya gençlik döneminde geçtiğine göre, her ne kadar akıl diye niteliyor olsa da 'doğal akıl' insani nefsin sınırlarına henüz girmemiştir. Yani hayvani akıl aşaması olmalıdır. Ondan önceki aşama ise 'yalın nefs' olarak nitelenmiş, akıl kavramı kullanılmamıştır. Bu aşamayı duyuların gelişme süreci olarak görür. Bu durum Gazali'de insanın bilme sürecinin tecrübe ile başladığı fikrini destekler niteliktedir". Eğer öyleyse bu, Gazali'de bir zihin olarak aklın işleme sürecinin nasıl bir temel ile başladığının cevabını verir. Erdem Gazali'nin akıl bilgisi üzerine yazmış olduğu makalede prensip olarak Gazali’nin anlayışında bilginin doğuştan gelmediğini söyler. Ancak o apriori bilgiyi de kabul etmektedir. Neticede Gazali epistemolojisinde bilginin duyu, akıl ve kalp (sezgi) olmak üzere üç kaynağı vardır. Erdem burada şu soruyu sorar, kalbi bilginin gelişinde aklın ilgisi var mı? Ortaya çıkan sonuç kalbin dış dünyaya açılabilmek için duyulara muhtaç oluşudur. Kalp dış dünyayı kullanabilmek için duyu vasıtalarını kullanmaktadır. Kalp, edineceği bilgiye ön hazırlık ve zemin olması bakımından duyu, akıl ve tecrübeye ihtiyaç

${ }^{4}$ Gazali'nin bilgiyi tecrübeden başlatması onu bir ampirist yapmaz. Çünkü Gazali deneyimi bu dünya içerisinde insanın algı olanağı olarak görüyor olmasıyla beraber bir dış destek olmadan onun doğruyu bulabilmesi mümkün değildir. Yani deney ve hatta akıl doğruyu bulmada yardımcıdırlar ama asla hakikatin memba değildirler.

Turkish Academic Research Review - Türk Akademik Araştırmalar Dergisi https://dergipark.org.tr/tr/pub/tarr 
duymaktadır. Bundan dolayı duyu ve akıl temelli bilgiler kalp için hiç de yabana atılmayacak veriler taşır (Erdem, 2013, s. 90-94).

Benzer şekilde El-Munkız'da: "İnsan yaratıldığı zaman özü itibariyle yalın ve boş bir haldedir. ...İnsanın âlemlerden haberdar olması, algı sayesinde gerçekleşir (Gazali, 2018a, s. 157).” Ülken'de onun bu açıklamalarından hareketle Gazali'de insanın yaratılışına bilgisiz başlamış ve âlemi algı ile bilebiliyor olduğuna değinir (Ülken, 1985, s. 131).

Sorun da tam olarak burada başlar. Anlama yoluna böyle bir adım ile başlamış olan akıl kendinden bağımsız olarak var olan doğruyu nasıl bilebilecektir? Öyle ki, duyu ile başlanılan bilgi edinme süreci idrak ile aşamalar kat eder. Ama bu aşamalarda yeterli değildir. Gazali idrake dair şunları söyler;

“...idrak, 'idrak edilen şeyin suretini almak’ demektir. Başka bir tabirle idrak, bir şeyin hakikatinin suretini almaktır. Çünkü bir şeyin hariçteki sureti, idrak edilen şeye hulul etmez. İdrak edilen, şeyin hakikatinin hariçteki benzeridir. Zira gerçekte hissedilen, hariçteki hakikat değil, hisseden duyu organında onun meydana gelen benzeridir." (Gazali, 1971a, s. 67).

Yani kişi bir şeyi idrak ettiğinde onu kendinden bağımsız olarak almaz. 'Hissedilen duyu organında onun meydana gelen benzerini' alır. Dolayısıyla da o şeyin bizzat hakikati ile değil, kişinin zihnine girmiş olan benzeri ile karşılaşır. Öyleyse insan, dışındaki bilgiyi kendinden bağımsız edinemez.

Aklın hangi anlamlara geldiği noktasında bakacağımız üçüncü eser İhya'dır. Gazali (1974 I, s. 209) İhya'nın akla dair yazısının hemen başında, aklın öneminin ispatına gerek kalmayacak kadar açık olduğunu belirtir. Aklın hakikatine yani onun ne olduğuna gelindiğinde konunun açıklı̆̆a kavuşabilmesi için “ 'akıl'ın da dört manada kullanıldığını ve bu gibi müşterek manalarda kullanılan kelimelerin bütün manasını bir araya toplayan bir ta'rif den ziyade her mananın ayrı ayrı ta'rif edildiğini bilmek gerektiğini belirtir. (Gazali, 1974 I, s. 214).

Demek ki insanda olduğu gibi akılda da tam tanım vermemekte ve onun birden fazla manası olduğunu söylemektedir. Buna bir başka eserinde de dikkat çeker. Tek bir tanımla yetinmek ona göre bir hayal olabilir. Bunun böyle olmasının nedeni onun ortak bir terim olmasına dayanır (Gazali, 2002, s. 157). Mişkat'ta da şunları söyler; "Bilmiş ol ki insan kalbinde bu kemale sahip olan bir göz vardır; buna kimi zaman ak1l, kimi zaman ruh, bazen de nefs-i insani denir. Haydi, bunu cumhurun 1stılahına uyarak 'akıl' diyelim.” (Gazali, 2017b, s. 26,27). 
Öyleyse Gazali, akıl kavramını kullanım ve ihtiva yönünden birden fazla anlama geldiği için akıl şudur demekten kaçınmakta ve akıl denildiğinde şu şu anlamların da kullanıldığı bilinmeli şeklinde birtakım açıklamalara başvurmaktadır. Kavram aynıdır ama karşılık geldiği anlamlar her zaman bir değildir.

Bu manaların ne olduğuna gelindiğinde dört madde sıralar;

1. "İnsanların diğer canlı hayvanlardan ayrılmasını sağlayan haslete akıl derler ki, insanlar yaratılışlarındaki bu akıl ile nazari ilimler öğrenmeye istidat kazanırlar." (Gazali, 1974 I, s. 215). Gazali ayna benzetmesini yinelemektedir. Akıl ayna ile sırrına benzemektedir. Burada akıl göze de benzer. İnsanın dışarıyı görmesinin aracı nasıl ki göz ise bir ayna nispetinde olan akıl aracıllğıyla da ilimler edinebilir. Kur'an ve şeri'at da gözün görebilmesi için gerekli olan güneş ışığı gibidir

2. Akıl ile hali hazırda bulunan, ikinin birden çok olduğu, bir şeyin aynı anda iki yerde bulunamayacağının bilinmesi gibi zorunlu analitik bilgiler kastedilir. Gazali bu türden bilgilere akıl denilmesinde bir sakınca olmadığını ama aklın sadece onlardan ibaret görülmesinin yanlış olacağı uyarısında bulunur.

3. Tecrübe ile elde edilen bilgi de akıl olarak görülür

4. Aklın belli bir dereceye gelip olgunlaşma durumudur. Kişinin elde ettiği bilgilerin sonuçlarını anlamaya başlayıp bunlarla amel ettiği akıldır (Gazali, 1974 I, s. 215, 216).

Dikkat etmek gerekir ki Gazali aklı dörde ayırmamakta dört farklı şekilde kullanıldığını çözümlemektedir. Genel anlamda aklı birincisi ifade etse de bir insanın akıllı olmasının şartı onu doğru eylemde kullanması olduğu için önemsenen yani en değerlisi, dördüncü akıldır (Gazali, 1974 I, s. 216; Bilgin; Erek, 2019, s. 1285, 1286).

Gazali doğru bilgiyi ameli akla dayandırarak insanı tekrar dünyaya ve onun pratik uygulamalarına yöneltmiş olur. Ameli aklın gelişmesi kişiyi doğru bilgide sabitlemeye yetmez. Çünkü Gazali’ye göre ameli akıl civaya benzer. Bu akıl için kullanılan hikmet kelimesi bu sebepten dolayı aslında bir mecazdır. Yani ameli akıl asla yerinde durmaz. Durumun ve şahısların değişmesiyle anında değişiverir (Gazali, 1971a, 98). Gazali’nin bu anlayışını Musa bir üst merhaleye taşır ve şu iddiada bulunur: “...Gazali’nin kendisinden yüzyıllar önce Augustine’in olduğu gibi özün dönüşebilecek bir oluşum olduğunun farkında olduğunu kesin olarak söyleyebiliriz (Musa, 2018, s. 293)."”

\footnotetext{
${ }^{5}$ Devamında ise ekler: "Fakat ayrıca bireysel özü soyutlanmış bir oluşum olarak değil, daha geniş bir kozmik gerçeklikle ilişkili olarak düşünüyordu. Bu daha geniş şemadan kopmaya çalışmak ona göre ayağına sıkan bir girişim olurdu." (Musa, 2018, s. 293).
}

Turkish Academic Research Review - Türk Akademik Araştırmalar Dergisi https://dergipark.org.tr/tr/pub/tarr 
Ihya'da aklın dört çeşit anlamda kullanılıyor olduğunu söylemesi diğer açıklamalarıyla bağlantılı olarak incelenirse, birinci maddedeki akıl 'insanın hakikati' anlamına gelen ruh, kalp, nefis anlamlarında da kullanılan akla karşılık gelir. İkincisi akla ait olan bir bilme biçimi, üçüncüsü zihin ve onun bilme süreçlerini açıklayan akıl olur. Dördüncüsü ise ameli akıldır ki insanı gerçek anlamda geliştirip hakikate yaklaştıran odur. Bizim için burada önemli olan nokta 'saf akıl' ve zihnin birebir aynı şeyler olmadığı ama Gazali’nin ikisini de 'akıl' olarak kullanmış olduğudur. 'Zihin' olarak nitelendirebileceğimiz akıl insani ve hayvani nefsi bir arada bulundurur. 'Saf akıl' ise onun cismani özelliklerinden soyutlanarak elde edilen tarafidır. Aralarındaki fark kapsam farkıdır. Yani her zaman aklın bütününe değil, bazen o bütünün içindeki parçalara işaret edilir.

Gazali'de akıl ve onun bilme sürecine ilişkin yapılan bu inceleme sonucunda karşımıza iki önemli nokta çıkar:

1. Gazali insanın bilgi edinme sürecini tecrübeden başlatmıştır. İnsanın anlama ve algılama yetisi yaşanılmışlığın etkisi içerisinde işlemektedir. Dolayısıyla insan bilgiyi doğrudan ve saf bir şekilde edinemez. Her üç eserde de değinmiş olduğu ayna benzetmesi insanın sınırlı yapısı ile bilgi arasında kurulan ilişkiyi gözler önüne sermektedir. İnsan sınırlı yaşantılarıyla kurulan anlam dünyası içerisinde düşünür. İnsanın bilme sürecinin böyle bir yapı içerisinde işliyor oluşu onun yanılma ihtimaliyle devamlı olarak karşı karşıya kaldığını göstermektedir.

2. İnsanı doğru bilgiye götüren ve onu gerçek anlamda diğer varlıklardan ayıran akıl 'insani nefs' tir. Ancak her zaman akıl ve düşünme derken tek başına insani nefsi kastetmez. İnsanın özsel yanı olan insani nefs ‘saf akıl' a karşı1ık gelir, insanın cevheridir.

İkinci sonuçtan hareketle ulaşılan birinci sonucu sorgulamak gerekir. Gazali insanın esasını duyulardan kopan 'saf akıl' olarak gördüğüne göre insan bedeninden sıyrılabildiği takdirde bu akıl aracılığıyla kesin bilgiye erişebilmelidir. Örneğin, Kutluer Gazali'nin Mişkat'taki akıl kavramıyla yanılmayan bir aklı kastetmiş olduğunu söyler (Kutluer, 2012, s. 514, 515). Gazali'de insanın isyan etmesinin nedeninin bedeni olduğunu açıkça belirtmiştir. Yani eğer insanda beden olmasaydı nefs isyan etmeyecek yani hata yapmayacaktı (Gazali, 1971b, s. 158). Ancak dikkat edilmelidir ki bu çıkarım, insanda bulunan hali ile olan akıldan tecrit edilerek ulaşılmış bir sonuçtur. Kutluer'de bunu, Gazali’nin aklı yanılmayan bir şey olarak konumlandırmıs olmasıyla birlikte bu aklın vehim ve hayal gibi birtakım perdelerden sıyrılmasının çok zor ve tam manasıyla öldükten sonra gerçekleşebileceğini 
söylediğini belirtmektedir (Kutluer, 2012, s. 515). Yani aklın yanılmadığı ancak akı1 insandan ayrı düşünüldüğünde mümkün olur. Akıl, insanın cisminden ayrı düşünülebilir ancak aklın dışında kalan hayvani nefsin edimleri insana has olmasa bile insan yaşadığı müddetçe onun ayrılmaz bir parçasıdır. Dolayısıyla akıl tek başına bırakıldığı takdirde yanılmazken, dünyada yaşayan insanda hiçbir zaman tek başına bulunmadığından her zaman yanılma ihtimaliyle karşı karşıyadır. Öyleyse metinde saf akıl olarak nitelendirdiğimiz 'insani nefs’ doğru bilginin bir dayanağı olarak sadece 'düşünülebilir' dir. Bu iddiayı Gazali’nin cevher anlayışından hareketle temellendirilebiliriz. Gazali aklın insanın cevheri olduğunu belirtmiştir. Peki, ama 'cevher' ile kastedilen nedir?

\section{Akıl Bir Cevherdir}

Gazali varlığı Allah ve Allah dışındaki bütün varlıklar olarak ikiye ayırmaktadır (Gazali, 2018b, s. 37). Ona göre Allah dışındaki varlıklar hâdistir. Yani bu ayrım, hâdis olanla hâdis olmayan bir başka ifade ile gerçekten olan ile geçici olanı ayırmak için yapılmıştır. Cevheri ise geçici olana ait bir nitelik olarak konumlandırır. Gazali bunu her var olan şey mekânda yer kaplayan (mütehayyiz) ve yer kaplamayan olarak ikiye ayrılır diyerek detaylandırır. Mekânda yer kaplamayan şey, var olabilmek için cisme ihtiyaç duyuyorsa "araz", hiçbir şeye bağlı değilse "Allah" olarak isimlendirilir. Mekânda yer kaplayan varlıklara eğer birleşik değilse “cevher-i ferd”, birleştiğinde ise "cisim” denilir. Dördü içerisinde gözlem yoluyla bilinebilenler sadece 'araz' ve 'cisim' dir (Gazali, 2018b, s. 37). Yani bir şeyin 'duyu' ile algılanabilmesi için cisim ve araz olması gerekir. Cevher ancak araz ile duyumsanabilir. Hatta araz, tam da cevheri duyumsatmak için vardır. Bu nedenle araz yer değiştirmez. Ancak böyle demesinin sebebi araz hareketten yoksun olduğu için değil asıl hareket cevherde gerçekleştiği içindir. Hatta değişim cevherin bir mekândan diğerine olan hareketine verilen bir isimdir. Ancak cevherin değişmesiyle arazın değişmesi yahut bir mekânda bulunması aynı şey değildir. Çünkü mekân ya da değişim cevherin zatına eklenen bir konu iken arazda değişim ya da mekânda bulunma onun zatına eklenen bir şey değildir. Onlar zaten bizzat arazdır. Cevher tek başına duyumsanamıyor olsa da düşünülebilmektedir. Hâlbuki mekân ya da değişimi düşünebilmek ancak cevher ile mümkündür. Bu da arazın belirli bir cevhere ait olmanın dışında müstakil bir zatı olmadığını gösterir (Gazali, 2018b, s. 38- 43).

Gazali'nin açıklamaları, Bolay’ın da belirttiği gibi, onun cevheri varlığın özü olarak görmediğini göstermektedir. Yani varlığın kesin bilgisi cevhere bağlanmaz. Bilindiği üzere Aristo töz olması bakımından cevheri varlığın temeli, özü ve değişmezi olarak görmüştür. Gazali’de ise cevher esas varlık değildir. Ama

Turkish Academic Research Review - Türk Akademik Araştırmalar Dergisi https://dergipark.org.tr/tr/pub/tarr 
öneminden dolayı varlığın izahını yapmaya yarar (Bolay, 2013, s. 136- 276). Öyleyse Gazali'de cevher varlığın temeli olmasa da insan varlığı cevher sayesinde algılayıp anlamlandırabilmektedir. Cevherin değeri de bu nispette konumlanır.

Gazali cevherin Yaratıcıya değil yaratılmışa ait bir özellik olduğunu vurgulamaktadır. Akla gelindiğinde o hem niteliği hem de neliği olması bakımından insanın cevheridir. Dolayısıyla Gazali’ye göre düşünme Yaratıcıya değil, yaratılmışa ait bir niteliktir. Düşünme ne kadar yüce ve değerli olsa da insan nefsinin ve insan aklının bir niteliğidir. Gazali burada şunu sorar; nasıl olur da cevherin Yaratıcısı onun nitelikleriyle nitelenir (Gazali, 2017a, s. 57, 59)? Yani Gazali aklı sadece ama sadece insana has görür.

Öyleyse akıl bir cevherdir. Ancak cevher yaratılmışa ait bir nitelik olup, önemi varlığın izahını yapmaya yarıyor oluşundan gelir. Cevherin varlığın esası olmaması Gazali'nin insanı değerlendiriş şekline etki eder. Gazali'nin yukarıdaki açılamalarında görüldüğü üzere bir şeyin 'duyu' ile algılanabilmesi için cisim ve araz olması gerektiğinden 'cevher' in duyumsanabilir olma şartı araza bağlanmıştır. Dolayısıyla Gazali insanı ona ilişen ilineklerden ve cisminden bağımsız değerlendirmez. Örneğin Gazali’ye göre ‘İnsan düşünen hayvandır' sözü onun sadece nefsine karşılık gelir. Oysa insan sadece nefisten ibaret değildir. O 'düşünen, ölümlü, boyu dik, gülen bir hayvan' dır. Gazali bu tarifin önceki tariften farkını hem nefsi hem de cismi kuşatmış oluşuna bağlar. İnsanın bütününün nefis, ruh ve cisimden oluştuğunu söyler (Gazali, 1971b, s. 135). Yani insan hayvandan nefs ile ayrilıyor olsa da hayvanla ortak olan ruh ve cismi de onu kuşatan niteliklerindendir. Bu nitelikler insan yaşadığı müddetçe ondan ayrılamadığına göre, her ne kadar özsel olmasa da insanı bunlardan tamamen soyutlamış olarak düşünmek onu eksik ve yanlış tanımaya neden olacaktır.

Gazali'nin Tehafüt'teki eleştirisi de bu noktaya dayanır. Sorunun temelinde, saf akıldan hareketle yola çıkmış olan bir akıl yürütmenin hakikati belirleme imkânının olmayışı vardır. Sorun onların bu konudaki akıl yürütme biçimlerindedir. Çünkü Gazali’ye göre filozoflar, hakikatin ölçüsünü kendi akıllarından hareketle belirlemeye çalışmışlardır. Örneğin Gazali, biz âlemin varlığının ebedi olarak sürmesini imkânsız görmüyoruz diyor. Yani mümkündür ama zorunlu değildir. Hangisinin olacağı hakkında fikir ortaya koymak aklın işi değildir (Gazali, 2005, s. 49; Bkz. Toktaş, 2017, s. 133). Griffel'ın da belirttiği gibi “Gazali ile ilgili dikkatli bir okuma, onun sadece şunu varsaydığını gösterecektir: Daha önce başka türlü gerçekleşmemiş ve gerçekleşmeyecek olsa bile, (nedensel) ilişki başka türlü gerçekleşebilir (Griffel, 2009, s. 434)." Çünkü insan akıl yürütmeye bu dünyadan 
başlamakta bundan dolayı edindiği bilginin imkân ve nispeti insanın algı alanı kadar olmaktadır. Hâlbuki hakikat, insanın anlam ve algı sınırları kadar olamaz. İnsan bilgisi sürekli bedeninin ve içinde bulunduğu dünyanın sınırlarıyla yüzleşir. Bu konuda Musa şu tespitte bulunur:

"Bilginin sınırlarının kendisi kendine dönüşlü akılda ortaya çıkar. Akıl yalnızca kendi sınırlarını tanımakla kalmaz, aynı zamanda sınırlarının uçurumunda veya dehlizinde ontolojik kıyılara açılır. Bu sınırsız ontolojik kıyı, bütün olasılıkların olasılıklı olduğunu tahayyül eder ama söyleyişli dil ve akla bağlı sınırlamalarla kısıtlanmıştır” (Musa, 2018, s. 258).

İnsan dünyada yaşamak zorunda olduğu müddetçe sadece dünyanın sınırlılıkları ile çevrelenmez aynı zamanda eylemek zorunda kalır. Eylemek zorunlu olarak değişmeyi gerektirir. Orman, Gazali'nin son derece önemli ve gelişmiş bir değişim idrakine sahip olduğunu ve Gazali’yi doğru anlamak için bunu göz önünde bulundurmanın şart olduğunu söyler. Bu değişim iki biçime sahiptir: zamansal değişme ve durumsal değişme. Zamansal değişme insanın ve tarihin zaman içerisindeki değişmesidir, durumsal değişme ise insanlar arasındaki farklılıklardır (Orman, 2012, s. 66, 68). Yukarıda görüldüğü üzere Gazali varlığı Allah ve Allah dışındaki diğer varlıklar olarak ikiye ayırır. Bu ayrım gerçekten var olan (değişmeyen) ve geçici olan (değişen) şeklinde de okunabilir. İnsanın bilme edimindeki amaç gerçekten var olan yani hakikattir. Ama insan değişen bir varlıksa onun değişmeyeni nasıl bilebilir olduğu Gazali düşüncesinin merkezi bir problematiği olarak belirmektedir.

Özetle akıl 'insanın' cevheridir. Ama Gazali insanın ne olduğunu irdelerken akıl cevherini büsbütün arazlarından ve cisminden sıyırarak değerlendirmemektedir. Öyleyse o, insana dolayısıyla da akla yaklaşırken kesin hatlar çizme, idealize etme gayretinde değildir. Doğrunun nasıl bulunabilir olduğunu irdelediği şeklide neden tam olarak bulunulamıyor olduğunu da göz önüne almıştır. Akıl insana tam da doğruyu yanlıştan ayırabilmesi için verilmiştir. Ama akıl yaşarken, neredeyse, hiçbir zaman saf halde bulunamadığına göre doğruyu tam bir şekilde kavrayamaz. Bu sebeple insan, akıl sahibi bir varlık olduğu kadar yanılan da bir varlıktır.

\section{Sonuç}

Araştırma üç ana başlıktan oluşmaktadır. Birinci başlıkta görülmektedir ki Gazali insanı 'akıl sahibi' bir varlık olarak nitelendirmektedir. İkinci başlık insandaki aklın ne anlama geldiğini soruşturmaktadır. Burada hem Gazali'nin 'akıl' derken neyi kastettiğine hem de aklın bilgiyi nasıl edindiğine bakılmıştır. Gazali'nin el-Mearif, el-

Turkish Academic Research Review - Türk Akademik Araştırmalar Dergisi https://dergipark.org.tr/tr/pub/tarr 
Mearic ve İhya'daki akıl anlayışları ana kaynak olarak incelenmiştir. Her üç eserde de Gazali'nin aklı aynaya benzetmiş olması dikkat çekmektedir. Aklın bir ayna gibi olması insanın hem nasıl bilebilir olduğunu gösterir hem de neden tam olarak bilemediğinin cevabını verir. Ayna yansıtma gücüyle dışarıyı görmeye olanak sağlar. Ancak kişinin bilgisi aynaya bağımlıdır. Yani aynanın yansıtma gücü nispetinde görebilir. Ayna akıl olduğuna göre insanın anlama ve algılama yetisi tecrübenin etkisi içerisinde işler. İnsan bilgiyi kendinden bağımsız edinemez. Gazali insanın sadece nefsini ve nefsinin taşıdığı vasıfları bilebileceğini söyler.

Gazali'de aklın anlamı ve onun bilme süreci karşımıza iki önemli sonuç çıkarır:

1. Gazali insanın bilgi edinme sürecini tecrübeden başlatmaktadır. İnsanın anlama ve algılama yetisi yaşanmışlığın etkisindedir. Dolayısıyla insan bilgiyi doğrudan ve saf bir şekilde edinememektedir. Sınırlı yaşantılarıyla kurulan anlam dünyası içerisinde düşünür. İnsanın bilme sürecinin böyle bir yapı içerisinde işliyor oluşu yanılma ihtimaliyle devamlı olarak karşı karşıya olduğunu gösterir.

2. İnsanı doğru bilgiye götüren ve onu gerçek anlamda diğer varlıklardan ayıran akıl 'insani nefs' tir. Ancak her zaman akıl ve düşünme derken (tek başına) insani nefsi kastetmez. İnsanın özsel yanı olan insani nefs 'saf akıl' a karşılık gelir ve insanın cevheridir.

İkinci sonuçtan hareketle birinci sonuca itiraz edilebilir. Gazali insanın esasını saf akıl olarak nitelendirdiğine göre insan bedeninden sıyrılabildiğinde "saf akıl' ile kesin bilgiye erişebilmelidir. Nitekim Gazali insana hata yaptıran şeyin onun bedeni olduğunu söyler. Yukarıda açıklanan bilme sürecinin ortaya böyle bir sonuç çıkardığı doğrudur. Ancak insanın bedeninden tam olarak sıyrılabildiği hiçbir zaman söylenemez. Öyleyse metinde saf akıl olarak nitelendirdiğimiz 'insani nefs' doğru bilginin bir dayanağı olarak sadece 'düşünülebilir' dir. Bu iddia Gazali’nin cevher anlayışından hareketle temellendirilebilir. Çünkü akıl insanın cevheridir. Üçüncü başlıkta Gazali'nin cevherden ne anladığı ve cevherin akıl ile olan irtibatı değerlendirilmiştir. Gazali’nin cevheri yaratılana ait bir nitelik olarak gördüğü ve cevherin varlığın esası olmadığı ortaya çıkmıştır. Cevher, insanın varlığı onun sayesinde algılayıp anlamlandırabildiği için değerlidir. Gazali’nin tam bu yüzden insanı ilinekleri ve cismiyle beraber yani cevherin dünyadaki 'duyumsanabilir' yaşantısı içerisinde değerlendirdiği görülmektedir.

Farklı eserlerden alınan akla ve onun mahiyetine ilişkin tüm bu açıklamalar uyumlu bir resim sunmaktadır. Örneğin, Gazali’nin aklı farklı anlamlarda kullanıyor 
oluşunun alt yapısında onun cevhere amaçsal değil araçsal bir anlam yüklemiş oluşu vardır. Böylece tek bir tanıma yahut bir kavrama bağlı kalmadan anlamın özüne inmeye çalışır. Gazali'nin akıl anlayışında karşımıza bir tutarsızlık olarak çıkan noktayı yeniden okumak da ancak bu şartlarda mümkün hale gelir. Onun aklı kimi yerde yanılan olarak nitelendirmesine karşın kimi yerlerde doğru bilgiye bir dayanak yapmış olması akıllarda soru işareti oluşturmuştur. Ancak anlıyoruz ki bu farklılık onun aklı farklı kapsamlarda kullanmaya tanıdığı olanaktan gelir. Kimi zaman insanın bütün bir bilme edimi (zihni) akıl anlamına gelebildiği gibi kimi zaman o zihnin özsel ve soyut yanı olan insani nefs kastedilir. Biri yanılmazken diğeri her an yanılma ihtimali taşır.

Sonuç olarak Gazali’nin akıl anlayışı üzerine yapılan bu soruşturma, onun aklı insanın dünyasal yaşantısından ayırmadan değerlendirdiğini göstermektedir. İnsan bu haliyle değişen ve sınırlı bir yapıdadır. Çünkü oluş ve bozuluşa tabidir. İnsan dünya yaşantısından bir diğer ifade ile bedeninden tam anlamıyla kopamadığına göre 'akıl sahibi' olmak 'yanılan bir varlık' olmak ile doğrusal bir ilişki içerisindedir. Akıl ve yanılma arasında kurulabilecek ters korelasyon aklın ikinci aşamasında insani nefsin desteğiyle mutlak yanılmaya engel olmak ve bunu en aza indirmek noktasında geçerli olabilir. Ancak idrak süreci hayvani nefsin verileri ile işlediğine göre akıl aslında yanılgılarla birlikte çalışır. Bu yüzden de insan akıl sahibi bir varlık olduğu için/kadar yanılan da bir varlıktır.

\section{Kaynakça}

Bilgin Ö. ; Erek İ. E. (2019). "İslam Ahlak Felsefesinde Akıl Ve Mutluluk İlişkisi”. Uluslararası Sosyal Araştırmalar Dergisi. 66: s. 1279- 1288.

Bolay, S. H. (2013). Aristo ve Gazzali Metafizikleri, Ankara: Nobel Yayınc1lı, 6. Basim

Erdem H. (2013). "Gazali’de Akı1 Bilgisi Ve Değeri”. Vefatının 900. Yll Anısına Büyük Mütefekkir Gazali. Diyanet İşleri Başkanlığı Yayınları, Ankara, s. 8396.

Gazali (1971a). Mukaddes Merdivenler. (Çev. Y. Arıkan). Eskin Matbaası: İstanbul.

Gazali (1971b). El Kıstasül Müstakim- Hak Yolcularının Miracı (Çev. Y. Arıkan). Eskin Matbaası: İstanbul.

Gazali (1974). İhyau Ulumi'd-Din (Çev. A. Serdaroğlu). Huzur Yayınevi, İstanbul.

Gazali (2002). Düşünmede Doğru Yöntem. (Çev. A. Kayacık). Ahsen Yayıncılık, İstanbul.

Turkish Academic Research Review - Türk Akademik Araştırmalar Dergisi https://dergipark.org.tr/tr/pub/tarr 
Gazali (2005). Filozofların Tutarsızlığı. (Çev. M. Kaya, H. Sarıoğlu). Klasik, İstanbul.

Gazali (2017a). Düşünme Konuşma Ve Söz Üzerine. (Çev. A. K. Cihan). İnsan Yayınları, İstanbul.

Gazali (2017b). Nur Metafiziği. (Çev. A. C. Köksal). Büyüyenay Yayınları, İstanbul.

Gazali (2018a). Dalaletten Çıkış Yolu. (Çev. O. Arpaçukuru). Beyan, Ankara.

Gazali (2018b). Itikadda Orta Yol. (Çev. O. Demir). Klasik, İstanbul.

Gazali (2019a). Kur'an'ın Cevherleri. (Çev. Ö. Türker). Hayy Kitap, İstanbul.

Gazali (2019b). Esmâ-ül Hüsnâ Şerhi. Dorlion Yayınları, Ankara.

Griffel F. (2009). Gazali'nin Felsefi Kelamı. Kalsik, İstanbul.

Kutluer İ. (2012). "Felsefe İle Tasavvuf Arasında: Gazali'nin Mişkatü'lEnvar'inda Entelektüel Perspektifler.". 900. Vefat Yllında İmam Gazzâlî Sempozyumu (2011). Marmara Üniversitesi İlahiyat Vakfi Yayınevi, İstanbul, s. 507- 534.

Musa İ. (2018). Gazali ve İmgelem Poetikası. (Çev. Ç. Taşkın). Hece Yayınları, Ankara.

Orman, Sabri (2012). Gazali’yi Anlamak: Bazı Metodolojik Mülahazalar. 900. Vefat Yilında İmam Gazzâlî Sempozyumu (2011). İstanbul: Marmara Üniversitesi İlahiyat Vakfi Yayınevi, s. 61- 76.

Toktaş F. (2017). "Üç Mesele-3: Ahiret Hayatının Mahiyeti: Cismani mi Ruhani mi?”. Gazzâlî Konuşmaları (2011). Küre Yayınları, İstanbul, s. 129- 173.

Ülken H. Z. (1985). İslam Felsefesi: Eski Yunan'dan Çağdaş Düşünceye Doğru, Ülken Yayınları, İstanbul.

Yıldız M. (2011). “Gazali’nin Akıl Eleştirisi” Tyb Akademi. 1: s. 71-85. 